Dragana Kragulj

UDK: 366.1:323.14(497.11)

Miloš Parežanin

323.14:378.18(497.11)

Slobodan Miladinović

Оригинални научни рад

University of Belgrade

Примљен: 15.01.2017.

Faculty of Organisational Sciences

doi:10.5937/socpreg1701059K

\title{
CONSUMER ETHNOCENTRISM IN TRANSITIONAL ECONOMIES: EVIDENCE FROM SERBIA ${ }^{1}$
}

Summary: This paper explores consumer ethnocentrism of young people among student population in the Republic of Serbia. The aim of the research is to examine whether there has been a growth in the level of consumer ethnocentrism among young people in Serbia given the increasingly adverse demographic and economic situation as well exceptional political turbulences in the country. The research was conducted by surveying students at the University of Belgrade by applying the CETSCALE and factor analysis techniques. The obtained values of the CETSCALE indicate that consumer ethnocentrism is within the limits of moderate, but it shows a slight increasing trend compared to the previous research. Three sets of factors are recognized: ethical ethnocentrism, economic patriotism and radical consumer ethnocentrism. The factors indicate that different intertwined motives influence young people's choice to buy local products. Preferences of young Serbian towards buying local products are the result of socio-economic environment, as well as a current political climate in Serbia.

Keywords: consumer, ethnocentrism, CETSCALE, student, Serbia.

\section{Introduction}

We live in a very dynamic time whose developmental imperative is openness of individual societies to a wide variety of mutual influences. Opening up of an individual society entails acceptance of many different external influences and willingness to adapt to change. Accordingly, the economic opening up involves a global exchange of people, goods and services, and thereby constant increase of market competition.

1 A part of this paper has done under the project "Tradition, Modernization and National Identity in Serbia and in the Balkans in Process of European Integration" (179074) which is implemented by the Centre for Sociological Research, Faculty of Philosophy in Niš, and funded by the Ministry of Education and Science of Republic of Serbia. 
Modern consumer society is characterized by greater availability and higher quality production one hand, and consumers who are increasingly rich, more educated and more attached to brands, on the other (Harrison, 2003). However, despite the globalization of modern market with all these features of global consumer society, the phenomenon of consumers' attachment to domestic products still persists. There are many factors that determine how ethnocentrism influences consumer behavior. However, it is very difficult to evaluate their individual strength and level of impact. The rationale for this should be sought in the complexity of factors that are influenced by historical, cultural, and global factors. Economic factors that determine the level of economic development, and social aspects that influence the attitudes of individuals towards external influences are also very important (Kosterman and Feshbach, 1989). Moreover, the concept of consumer ethnocentrism is precisely based on the pursuit of consumers to favour domestic over foreign products.

From the perspective of the Republic of Serbia, the problem is that its society has not yet got overall the "childhood diseases" of transition. The biggest problem lies in the (in)ability of Serbian companies to respond adequately to market conditions and improve their competitiveness. There are a few examples of Serbian companies that have managed to achieve this goal. The Serbian market has since become widely stocked with imported goods. Therefore, as expected, a domestic consumer faces the dilemma which product to buy, whether to opt for domestic or imported one.

The aim of this article is to analyze the degree of consumer ethnocentrism of the youth, particularly of the student population in the Republic of Serbia. Also, the purpose of this research is to compare the obtained results with the results of other relevant empirical research in Serbia and abroad. The article is structured as follows. After the introductory part, demographic, economic and political factors that may influence the consumer ethnocentrism in the Republic of Serbia are briefly explained; The next section (Section 3) surveys the literature on the background of consumer ethnocentrism; Section 4 gives a short overview of applied methodology where the emphasis is on the application of the CETSALE and techniques of factor analysis; Section 5 presents and discusses the results of the research through three isolated dominant factors of consumer ethnocentrism, but also gives the comparison with previous research in Serbia that are done based on the same methodology. The last section concludes and summarizes the research results and offers some limitations of the research.

\section{Demographic, economic and political environment}

The starting ascertainment of the research on consumer ethnocentrism of the youth in the Republic of Serbia was that, above all, demographic, economic and political factors in the country shape public opinion and influence domestic consumer prefer- 
ences. The demographic factor describes the unfavourable demographic structure of the country i.e. a pronounced trend of demographic aging of the population of Serbia, which is visible through the population aging index. Serbia belongs to demographically oldest nations in Europe. Natural population growth is consistently negative; according to the last 2011 census, the birth rate stood at -5.2 per 1000 people. The life expectancy of the population is extended and for men it is 71.0 and for women 76.1 years. However, compared to the developed countries of Europe, this data is very unfavourable. The share of the working age population (15-64 years old) in the total population is relatively stable. There is a noticeable trend of increasing average age of the total population of the Republic of Serbia (Statistical Office of the Republic of Serbia, 2015).

Projections of the labor force by the year 2020 indicate a decrease in the share of working age population (15-64 years old) in the overall population, as well as the growth of demographic dependency rate of the elderly population (the ratio of elderly to the working age population). (Statistical Office of the Republic of Serbia, 2011). These demographic trends have significant economic implications for economic growth of Serbia.

Table 1. Demographic indicators in Serbia (2006-2014)

\begin{tabular}{|c|c|c|c|c|c|c|}
\hline \multirow[b]{2}{*}{ Indicators } & \multicolumn{2}{|c|}{ Population } & \multicolumn{2}{|c|}{$\begin{array}{l}\text { Share in the total } \\
\text { population (in \%) }\end{array}$} & \multirow{2}{*}{$\begin{array}{l}\text { The } \\
\text { average } \\
\text { age of the } \\
\text { population }\end{array}$} & \multirow[b]{2}{*}{$\begin{array}{l}\text { Ageing } \\
\text { index }\end{array}$} \\
\hline & $\begin{array}{l}\text { Active } \\
\text { labor } \\
\text { force }(15- \\
64 \text { years })\end{array}$ & $\begin{array}{c}65 \\
\text { and over }\end{array}$ & $\begin{array}{c}\text { Active labor } \\
\text { force }(15-64 \\
\text { years })\end{array}$ & $\begin{array}{c}65 \\
\text { and over }\end{array}$ & & \\
\hline Year & & & & & & \\
\hline 2006 & 4978407 & 1203779 & 67.17 & 16.26 & 40.70 & 101.40 \\
\hline 2007 & 4967517 & 1202204 & 67.29 & 16.31 & 40.90 & 103.20 \\
\hline 2008 & 4959456 & 1194693 & 67.47 & 16.28 & 41.10 & 105.90 \\
\hline 2009 & 4954984 & 1181544 & 67.68 & 16.15 & 41.20 & 108.60 \\
\hline 2010 & 4955764 & 1164520 & 67.97 & 15.97 & 41.30 & 111.40 \\
\hline 2011 & 4943600 & 1182145 & 68.34 & 16.34 & 41.50 & 121.90 \\
\hline 2012 & 4908781 & 1190407 & 68.19 & 16.53 & 42.20 & 125.30 \\
\hline 2013 & 4862126 & 1210409 & 67.84 & 16.89 & 42.40 & 129.32 \\
\hline 2014 & 4908781 & 1235785 & 67.39 & 17.32 & 42.57 & 133.16 \\
\hline
\end{tabular}

Source: Statistical Office of the Republic of Serbia (2015). Statistical Database. Belgrade: Statistical Office of the Republic of Serbia $<$ http://webrzs.stat.gov.rs/WebSite/ $>1.12 .2015$. 
D. Kragulj, M. Parežanin, S. Miladinović, Consumer Ethnocentrisam...

What further negatively affects the economic progress of Serbia is the fact that despite the existence of relatively stable contingent of the working-age population, there has been a constant increase of the unemployment rate from 2008 to 2012. It has a significant influence on the living standard and purchasing power of the population (Table 2).

Table 2. Key macroeconomic indicators for Serbia (2006-2014)

\begin{tabular}{|l|c|c|c|c|c|c|c|c|c|}
\hline Indicators & 2006 & 2007 & 2008 & 2009 & 2010 & 2011 & 2012 & 2013 & 2014 \\
\hline $\begin{array}{l}\text { Real GDP } \\
\text { growth (in \%) }\end{array}$ & 4.9 & 5.9 & 5.4 & -3.1 & 0.6 & 1.4 & -1.0 & 2.6 & -1.8 \\
\hline $\begin{array}{l}\text { Consumer } \\
\text { prices (in \%, } \\
\text { relative to the } \\
\text { same month a } \\
\text { year earlier) }\end{array}$ & 6.6 & 11.0 & 8.6 & 6.6 & 10.3 & 7.0 & 12.2 & 2.2 & 1.7 \\
\hline $\begin{array}{l}\text { Exports (in } \\
\text { EUR million) }\end{array}$ & 6,948 & 8,110 & 9,583 & 8,043 & 9,515 & 11,145 & 11,469 & 13,937 & 14,451 \\
\hline $\begin{array}{l}\text { - growth rate } \\
\text { in \% com- } \\
\text { pared } \\
\text { to a year } \\
\text { earlier }\end{array}$ & 30.4 & - & 18.2 & -16.1 & 18.3 & 17.1 & 2.9 & 21.5 & 3.7 \\
\hline $\begin{array}{l}\text { Imports (in } \\
\text { EUR million) }\end{array}$ & 11,970 & 15,468 & 18,267 & 13,099 & 14,244 & 16,487 & 16,992 & 17,782 & 18,096 \\
\hline $\begin{array}{l}\text { - growth rate } \\
\text { in \% com- } \\
\text { pared } \\
\text { to a year } \\
\text { earlier }\end{array}$ & 24.5 & - & 18.1 & -28.3 & 8.7 & 15.7 & 3.1 & 4.7 & 1.8 \\
\hline $\begin{array}{l}\text { Current ac- } \\
\text { count balance } \\
\text { (in EUR mil- } \\
\text { lion) }\end{array}$ & $-2,356$ & $-5,474$ & $-7,125$ & $-2,032$ & $-2,037$ & $-3,656$ & $-3,671$ & $-2,098$ & $-1,985$ \\
\hline $\begin{array}{l}\text { Current ac- } \\
\text { count balance } \\
\text { (as\% of GDP) }\end{array}$ & -9.6 & -18.6 & -21.1 & -6.6 & -6.8 & -10.9 & -11.6 & -6.1 & -6.0 \\
\hline $\begin{array}{l}\text { Unemploy- } \\
\text { ment accord- } \\
\text { ing to the } \\
\text { Survey (in \%) }\end{array}$ & 20.9 & 18.1 & 13.6 & 16.1 & 19.2 & 23.0 & 23.9 & 22.1 & 19.2 \\
\hline $\begin{array}{l}\text { Wages (aver- } \\
\text { age for the } \\
\text { period, in } \\
\text { EUR) }\end{array}$ & 260.0 & 347.1 & 400.5 & 337.4 & 330.1 & 372.5 & 364.5 & 388.6 & 379.3 \\
\hline
\end{tabular}




\begin{tabular}{|l|c|c|c|c|c|c|c|c|c|}
\hline $\begin{array}{l}\text { RS budget } \\
\text { deficit/surplus } \\
\text { (in \% of GDP) }\end{array}$ & -1.7 & -1.6 & -1.7 & -3.2 & -3.4 & -4.0 & -5.9 & -5.2 & -6.3 \\
\hline $\begin{array}{l}\text { RS public } \\
\text { debt, (external } \\
\text { + internal, in } \\
\% \text { of GDP }\end{array}$ & 35.9 & 29.9 & 28.3 & 32.8 & 41.8 & 45.4 & 56.2 & 59.6 & 70.4 \\
\hline $\begin{array}{l}\text { RSD/EUR } \\
\text { exchange rate } \\
\text { (average, in } \\
\text { the period) }\end{array}$ & 84.11 & 79.96 & 81.44 & 93.95 & 103.04 & 101.95 & 113.13 & 113.14 & 117.31 \\
\hline $\begin{array}{l}\text { RSD/EUR } \\
\text { exchange rate } \\
\text { (end of pe- } \\
\text { riod) }\end{array}$ & 79.00 & 79.24 & 88.60 & 95.89 & 105.50 & 104.64 & 113.72 & 114.64 & 120.96 \\
\hline $\begin{array}{l}\text { GDP (in EUR } \\
\text { million) }\end{array}$ & 24,435 & 29,452 & 33,705 & 30,655 & 29,766 & 33,424 & 31,683 & 34,263 & 33,319 \\
\hline
\end{tabular}

Source: National Bank of Serbia (2015). Key macroeconomic indicators. Belgrade: National Bank of Serbia. $<$ http://www.nbs.rs/internet/english/80/index.html $>1.12 .2015$.

Compared to other European countries, Serbia began its transition process late. Serbia has started to implement the transition process, which involves complex social, economic and political reforms (Kragulj, 2013), only since 2000, and it has not been finished yet. The economic factor is reflected in the continuously unfavorable economic situation in the country in the past quarter of the century, with a predominantly negative trend of all relevant macroeconomic indicators, low living standard, an unfavourable investment climate and the lack of FDI for completion of economic reforms and transition processes (Šestović and Miović, 2013; Estrin and Uvalic, 2014). There is a constant budget deficit and a relatively low and unstable GDP growth rate with negative values in 2009, 2012 and 2014 (National Bank of Serbia, 2015). One cannot neglect the impact of the global financial crisis on the Serbia's economy.

The consequences on the real sector of the economy are dominantly manifested in the absence of funds, increased capital outflows from the economy and the decline in the inflow of foreign direct investments, necessary for the continuation of reforms. The shortage of capital has led to more expensive loans on one hand, and to the increased number of non-performing loans, on the other. The decline of FDI inflows has resulted in insufficient creation of new production capacities, which has resulted in the lack of new jobs, anemic export growth and its unfavourable structure, as well as holding back economic growth of the country.

Dominant political factors are primarily related to long-term efforts of the Govern- 
D. Kragulj, M. Parežanin, S. Miladinović, Consumer Ethnocentrisam...

ment of the Republic of Serbia to achieve simultaneously two very important objectives: faster progress into the European integration process and the preservation of sovereignty and territorial integrity of the country (the problem of Kosovo) (Hrvatin and Trampuž, 2000; Korovilas, 2002). In fact, all the countries of the Western Balkans (Albania, Bosnia and Herzegovina, Montenegro, Croatia, Macedonia, Serbia) see their economic and political future in the European Union. Numerous reforms that have been implemented in these countries imply harmonization of the standards with those of the united Europe's in all spheres of economic and social life (Kragulj, 2013). These countries are at different stages of accession to the European Union. Croatia has gone furthest ahead, becoming a full member of the EU on 1 July 2013. Serbia was granted candidate status and started accession negotiations with the EU on 21 January 2014 , but the date of full membership and the dynamics of the negotiations remain uncertain.

Table 3. Process of European integration of the Western Balkans

\begin{tabular}{|c|c|c|c|c|c|c|c|c|}
\hline $\begin{array}{l}\text { European } \\
\text { integration of } \\
\text { the Western } \\
\text { Balkans }\end{array}$ & $\begin{array}{l}\text { Beginning } \\
\text { of the } \\
\text { Stabiliza- } \\
\text { tion and } \\
\text { Association } \\
\text { Process }\end{array}$ & $\begin{array}{l}\text { Feasibility } \\
\text { Study }\end{array}$ & $\begin{array}{l}\text { Start of ne- } \\
\text { gotiations }\end{array}$ & $\begin{array}{l}\text { The sign- } \\
\text { ing of the } \\
\text { SAA }\end{array}$ & $\begin{array}{l}\text { Submitted } \\
\text { candidacy } \\
\text { for mem- } \\
\text { bership in } \\
\text { the EU }\end{array}$ & $\begin{array}{l}\text { Becoming } \\
\text { a candidate }\end{array}$ & $\begin{array}{l}\text { Negotia- } \\
\text { tions for } \\
\text { member- } \\
\text { ship }\end{array}$ & $\begin{array}{c}\text { Achieved } \\
\text { member- } \\
\text { ship }\end{array}$ \\
\hline Croatia & $\begin{array}{l}\text { Yes - } \\
1999 .\end{array}$ & $\begin{array}{c}\text { Yes } \\
-\quad \text { May } \\
2000 .\end{array}$ & $\begin{array}{c}\text { Yes - } \\
\text { November } \\
2000 .\end{array}$ & $\begin{array}{l}\text { Yes - } \\
\text { October } \\
2001 .\end{array}$ & $\begin{array}{l}\text { Yes - } \\
\text { February } \\
2003 .\end{array}$ & $\begin{array}{c}\text { Yes } \\
\text { - } \quad \text { June } \\
2004 .\end{array}$ & $\begin{array}{l}\text { Yes - } \\
\text { October } \\
2005 .\end{array}$ & $\begin{array}{l}\text { July 1, } \\
2013 .\end{array}$ \\
\hline Macedonia & $\begin{array}{l}\text { Yes - } \\
1999 .\end{array}$ & $\begin{array}{l}\text { Yes } \\
-\quad \text { June } \\
1999 .\end{array}$ & $\begin{array}{l}\text { Yes } \\
-\quad \text { March } \\
2000 .\end{array}$ & $\begin{array}{l}\text { Yes - } \\
\text { April } \\
2001\end{array}$ & $\begin{array}{l}\text { Yes - } \\
\text { March } \\
2004 .\end{array}$ & $\begin{array}{c}\text { Yes - } \\
\text { December } \\
2005 .\end{array}$ & No & \\
\hline Albania & $\begin{array}{l}\text { Yes - } \\
1999 .\end{array}$ & $\begin{array}{l}\text { Yes } \\
\text { - June } \\
2001 .\end{array}$ & $\begin{array}{c}\text { Yes - } \\
\text { January } \\
2003 .\end{array}$ & $\begin{array}{l}\text { Yes - } \\
\text { June } \\
2006 .\end{array}$ & $\begin{array}{l}\text { Yes - } \\
\text { April } \\
2009 .\end{array}$ & $\begin{array}{c}\text { Yes } \\
\text { - } \quad \text { June } \\
2014 .\end{array}$ & No & \\
\hline Serbia & $\begin{array}{l}\text { Yes - } \\
2001 .\end{array}$ & $\begin{array}{c}\text { Yes } \\
-\quad \text { April } \\
2005 .\end{array}$ & $\begin{array}{c}\text { Yes - } \\
\text { October } \\
2005 .\end{array}$ & $\begin{array}{l}\text { Yes - } \\
\text { April } \\
2008 .\end{array}$ & $\begin{array}{c}\text { Yes - } \\
\text { December } \\
2009 .\end{array}$ & $\begin{array}{l}\text { Yes - } \\
\text { March } \\
2012 \text {. }\end{array}$ & $\begin{array}{l}\text { Yes - } \\
\text { January } \\
2014 .\end{array}$ & \\
\hline Montenegro & $\begin{array}{l}\text { Yes - } \\
2001 .\end{array}$ & $\begin{array}{c}\text { Yes } \\
-\quad \text { April } \\
2005 .\end{array}$ & $\begin{array}{l}\text { Yes - } \\
\text { October } \\
2005 .\end{array}$ & $\begin{array}{l}\text { Yes - } \\
\text { October } \\
2007 .\end{array}$ & $\begin{array}{c}\text { Yes - } \\
\text { December } \\
2008 .\end{array}$ & $\begin{array}{c}\text { Yes - } \\
\text { November } \\
2010 .\end{array}$ & $\begin{array}{l}\text { Yes - } \\
\text { June } \\
2012 \text {. }\end{array}$ & \\
\hline $\begin{array}{l}\text { Bosnia and } \\
\text { Herzegovina }\end{array}$ & $\begin{array}{l}\text { Yes - } \\
1998 .\end{array}$ & $\begin{array}{c}\text { Yes - } \\
\text { November } \\
2003 \text {. }\end{array}$ & $\begin{array}{c}\text { Yes - } \\
\text { November } \\
2005 \text {. }\end{array}$ & $\begin{array}{l}\text { Yes - } \\
\text { June } \\
2008 .\end{array}$ & $\begin{array}{c}\text { Yes - } \\
\text { February } \\
2016 .\end{array}$ & No & No & \\
\hline
\end{tabular}

Source: Adapted from (Budimir, et al., 2008) and updated by authors. 
All Western Balkan countries are facing primarily institutional and economic obstacles in the EU accession process. The Republic of Serbia's way is additionally burdened with the issue of Kosovo, which leads to dissatisfaction of the population and strengthen nationalism (Berna, 2013).

\section{Background of consumer ethnocentrism in Serbia and literature review}

The concept of consumer ethnocentrism has been widely discussed in the literature. It was first developed as a sociological phenomenon (Bar-Tal, 1990; Block and Block, 1951; Forbes, 1985; Levine and Campbell, 1972; Rokeach, 1948), and later got its application in economics and marketing research (Cordell, 1992; Druckman, 1968; Ram and Sheth, 1989; Watson and Wright, 2000). The very notion of ethnocentrism was introduced by Sumner (1906), who defines ethnocentrism as a "view of things in which one's group is the center of everything, and others are scaled and rated with reference to it." From the perspective of marketing, consumer ethnocentrism should be considered as consumer choice that is conditioned by the attitude that in this way he/she helps not only economic but also political and social development of the country. Therefore ethnocentric consumers op for domestic rather than foreign products. In other words, to some extent, consumers are more ready to give their trust to domestic companies and domestic products than to foreign companies and imported products. Such consumer's attitude is categorized as an act of patriotism (Shimp and Sharma, 1987). If a consumer choice is a foreign product, such behavior is considered unpatriotic. (Klein, 2002). Buying foreign products represents unpatriotic act because it leads to an increase in unemployment rate and harm the local economy (Shimp, 1984). Based on this view, the CETSCALE (Consumer Ethnocentric Tendency Scale) is developed, which was first empirically verified in the US economy (Shimp and Sharma, 1987) and was later accepted and applied in studies across the world as a concept for measuring consumer ethnocentrism.

Crawford and Lamb (1981) showed that the purchase of foreign products may cause a severe emotional response in the consumer if it is linked with the economic development of the country and the loss of jobs in their home country. This argument along with a practical application of the CETSCALE helped ethnocentrism to shift from the sphere of psychology and sociology to the domain of marketing, and to become a significant factor in the research on consumer choice (Klein and Ettenson, 1999). Some studies have shown that, although consumer ethnocentrism exists, it does not affect the rational behavior of consumers (Balabanis and Diamantopoulos, 2004; Sirgy, 1982; Vida and Reardon, 2008; Yoo and Donthu, 2005). Depending on 
D. Kragulj, M. Parežanin, S. Miladinović, Consumer Ethnocentrisam...

the specific situation caused by various factors, consumers will opt for either a domestic or foreign product (Schnettler, et al., 2011). In order to better comprehend its essence, it is necessary to perceive consumer ethnocentrism in the light of socioeconomic and political context of a particular country.

Empirical studies in many countries have shown the validity and practical application of the CETSCALE (Table 4). In most countries consumer ethnocentrism is located within the limits of moderate ethnocentrism: the US (Durvasula, et al., 1997; Hult, et al., 1999; Shimp and Sharma, 1987), Poland (Good and Huddleston, 1995; Vida and Fairhust, 1999), Malta (Caruana, 1996), Indonesia (Hamin and Elliott, 2006), the Czech Republic, Hungary, Estonia (Vida and Fairhust, 1999), New Zealand (Watson and Wright, 2000) and others. In Russia (Durvasula, et al., 1997), Belgium, the UK and Greece (Steenkamp and Baumgartner, 1998) there is a mild consumer ethnocentrism (the scale values between 28 and 38). Somewhat more pronounced ethnocentrism is present in South Korea (Sharma, et al., 1995), Malaysia (Shah and Ibrahim, 2012) and Indonesia (Hamin and Elliott, 2006).

\section{Table 4. A review of research of consumer ethnocentrism}

\begin{tabular}{|l|c|c|c|}
\hline Author & Country & Respondent & Mean \\
\hline Caruana (1996) & Malta & General population & 58.8 \\
\hline $\begin{array}{l}\text { Chryssochoidis, Krystallis \& Perreas } \\
\text { (2007) }\end{array}$ & Greece & General population & 65.45 \\
\hline \multirow{2}{*}{$\begin{array}{l}\text { Durvasula, Andrews \& Netemeyer } \\
\text { (1997) }\end{array}$} & USA & Students & 50.24 \\
\hline \multirow{2}{*}{$\begin{array}{l}\text { Good \& Huddleston (1995) } \\
\text { Nussia }\end{array}$} & Poland & General population & 69.19 \\
\hline Hamin \& Elliot (2006) & Russia & General population & 51.68 \\
\hline \multirow{2}{*}{$\begin{array}{l}\text { Hult, Keillor \& Lafferty(1999) } \\
\text { Indonesia }\end{array}$} & General population & 74.5 \\
\hline & USA & Students & 61.5 \\
\hline & Japan & General population & 40.1 \\
\hline Schnettler et al. (2011) & Sweden & General population & 38.4 \\
\hline Shah \& Ibrahim (2012) & Chile & General population & 52.9 \\
\hline Sharma, Shimp \& Shin (1995) & Malaysia & General population & 79.64 \\
\hline Shimp \& Sharma (1987) & Gouth Korea & General population & 85.07 \\
\hline
\end{tabular}




\begin{tabular}{|l|c|c|c|}
\hline \multirow{3}{*}{ Steenkamp \& Baumgartner (1998) } & Belgium & General population & 28.7 \\
\cline { 2 - 4 } & Great Britain & General population & 30.29 \\
\cline { 2 - 4 } & Greece & General population & 37.84 \\
\hline Veljković (2009) & Serbia & General population & 57 \\
\hline \multirow{3}{*}{ Vida \& Fairhust (1999) } & Czech Republic & Students & 45.17 \\
\cline { 2 - 4 } & Estonia & Students & 53 \\
\cline { 2 - 4 } & Hungary & Students & 59 \\
\cline { 2 - 4 } & Poland & Students & 43.3 \\
\hline Watson \& Wright (2000) & New Zealand & General population & 50.61 \\
\hline Wong et al. (2008) & China & Students & 56.25 \\
\hline
\end{tabular}

Source: Adapted from (Hamin and Elliott, 2006; Teo, et al., 2011) and updated by authors.

A factor analysis is used to isolate factors that influence the degree of consumer ethnocentrism. These factors are named differently in various studies. In a study conducted in Greece two factors were identified and called hard ethnocentrism and soft ethnocentrism (Chryssochoidis, et al., 2007). Upadhyay and Singh (2006) identify four factors (nationalism, socio-economic conservatism, protectionism and ultranationalism). In Singapore protectionism and conservatism were identified as a result of the factor analysis of consumer ethnocentrism (O'cass and Lim, 2002). Acharya and Elliott (2003) recognize emotional and rational consumer ethnocentrism as factors of consumer ethnocentrism in Australia. Depending on the intensity of consumer ethnocentrism the factors are also called economic protectionism, patriotism and pragmatism or the factors of trade, country preferences and employment (Strehlau, et al., 2012). In the Republic of Serbia several studies on consumer ethnocentrism have been conducted (Marinković, et al., 2011; Miladinović, 2012; Veljković, 2009; Vida, et al., 2008). Individual factors have not been isolated in these studies, except in the study conducted in 2011 in which consumer patriotism, politically motivated consumer ethnocentrism, ethical ethnocentrism, and radical ethnocentrism were isolated as components of consumer ethnocentrism (Miladinović, 2012).

\section{Short overview of methodology applied}

This research uses the original poll (Shimp and Sharma, 1987) which forms the basis of the CETSALE. The poll contains 17 claims that are measured using a 1-7 
Likert scale, where 1 denotes absolute refusal of ethnocentrism, and 7 full compliance with consumer ethnocentrism. Values of the CETSCALE range from 17 to 119, where the result of 17 determines theoretical minimum value of absolutely non-ethnocentric consumers, and 119 represents theoretical maximum value of absolutely ethnocentric consumers (Shimp and Sharma, 1987).

The survey was conducted on a sample of the student population of the University of Belgrade, Faculty of Organizational Sciences in May 2014. The survey included 577 respondents of both sexes. The age of respondents was 18-25 years, all residing in Belgrade. Due to the structure of the sample it was not possible to carry out detailed analysis by features such as age, residence, education level and ethnicity (characteristics are the same for the whole sample), and this appears to bee limitation of the study.

Based on the analysis of the existing research on consumer ethnocentrism as well as current social, economic and political circumstances in Serbia, three hypotheses are posed here:

H1: There is a moderate consumer ethnocentrism among young people in Serbia.

$\mathrm{H} 2$ : There is a rise in consumer ethnocentrism among young people in Serbia.

H3: It is possible to identify groups of factors that influence consumer ethnocentrism among young people in Serbia.

The research starts from the assumption hypothesis 1 that the consumer ethnocentrism in young people is more moderate compared to that in the older population (Witkowski, 1998). The assumption is consistent with studies conducted in the Republic of Serbia and the countries that have already gone through the transition process (Vida, et al., 2008). Also, the hypothesis 2 and hypothesis 3 are based on previously conducted research where the factors of consumer ethnocentrism are successfully identified (Acharya and Elliott, 2003; Chryssochoidis, et al., 2007; Miladinović, 2012; O'cass and Lim, 2002; Strehlau, et al., 2012; Upadhya and Singh, 2006). It is expected that the statistical data analysis will isolate the factors from a collected sample of the student population. The factor analysis (varimax rotation) has been performed in the article and the findings have been then compared with the previous research.

\section{Results and discussion}

The data analysis has determined the total CETSCALE value of 65.22 and the mean value of 3.84, which indicates the presence of moderate consumer ethnocentrism in the student population of Serbia, thus confirming hypothesis hypothesis 1 . Previous studies conducted in Serbia had showed that the CETSALE value was 62.6 in 2005 and 57.0 in 2008 (Veljković, 2009), 63.35 in 2011 (Marinković, et al., 2011); 
60.51 in 2012 (Miladinović, 2012). This shows that the trend in the analyzed studies from 2005-2012 was variable, but within the limits of moderate consumer ethnocentrism. The growth of consumer ethnocentrism appears in 2014 and reaches the highest value of the CETSCALE in research to date. Thus, comparing our results with previous studies, hypothesis 2 may be accepted, i.e. the claim that there is an increase in consumer ethnocentrism among young people in Serbia can be also accepted.

The cause of slight increase in consumer ethnocentrism among young people in Serbia can be sought in situational factors, primarily political and economic. The escalation of the Kosovo crisis and the pressures of the international community that preceded the signing of the Brussels agreement on the normalization of relations between Belgrade and Pristine in April 2013is certainly seen as a prominent political factor. Part of the answer must be sought in the recent changes in the structure of political power, i.e. coming to power of forces that until recently declared themselves as nationalists, and calling themselves now "the European road."

Recent public opinion polls have shown that the number of those who support European integration at the expense of recognition of the independence of Kosovo has reduced in Serbia (European Integration Office, 2011, 2012, 2013), along with also significant reduction of the already low support to Serbia's accession to NATO. The rating of democratic parties is also in constant decline due to relatively poor economic performance in a twelve-year continuous power and their shift into opposition.

Economic problems are manifested in full strength and affect almost all sectors and all citizens of Serbia: high unemployment rate, low real wages and decline in living standard, a huge foreign trade deficit, excessive indebtedness of the country, bloated and inefficient public sector, unsuccessfully implemented privatization, high level of corruption in all spheres and so on. (European Bank for Reconstruction and Development, 2014). 
D. Kragulj, M. Parežanin, S. Miladinović, Consumer Ethnocentrisam...

Table 5. Means and SD of statements

\begin{tabular}{|l|c|c|c|}
\hline Statement & N & Mean & SD \\
\hline $\begin{array}{l}\text { Serbian people should always buy Serbian-made } \\
\text { products instead of imports. }\end{array}$ & 577 & 4,29 & 1.724 \\
\hline $\begin{array}{l}\text { Only those products that are unavailable in Serbia } \\
\text { should be imported. }\end{array}$ & 577 & 5,06 & 1.771 \\
\hline Buy Serbian-made products. Keep Serbia working. & 577 & 5,57 & 1.390 \\
\hline Serbian products, first, last, and foremost. & 577 & 4,28 & 1.752 \\
\hline Purchasing foreign-made products is un-Serbian. & 577 & 2,34 & 1.515 \\
\hline $\begin{array}{l}\text { It is not right to purchase foreign products, because it } \\
\text { puts the Serbian people out of jobs. }\end{array}$ & 577 & 3,30 & 1.634 \\
\hline $\begin{array}{l}\text { A real Serbian should always buy Serbian-made } \\
\text { products. }\end{array}$ & 577 & 3,14 & 1.762 \\
\hline $\begin{array}{l}\text { We should purchase products manufactured in Serbia } \\
\text { instead of letting other countries get rich off us. }\end{array}$ & 577 & 4,45 & 1.704 \\
\hline It is always best to purchase Serbian products. & 577 & 3,63 & 1.726 \\
\hline $\begin{array}{l}\text { There should be very little trading or purchasing of } \\
\text { goods from other countries unless out of necessity. }\end{array}$ & 577 & 3,14 & 1.640 \\
\hline $\begin{array}{l}\text { Serbian people should not buy foreign products, } \\
\text { because this hurts Serbian business and causes } \\
\text { unemployment. }\end{array}$ & 577 & 3,49 & 1.556 \\
\hline $\begin{array}{l}\text { Curbs should be put on all imports. } \\
\text { It may cost me in the long-run but I prefer to support } \\
\text { Serbian products. }\end{array}$ & 577 & 4,17 & 1.638 \\
\hline $\begin{array}{l}\text { Foreigners should not be allowed to put their products } \\
\text { on our markets. }\end{array}$ & 577 & 2,66 & 1.522 \\
\hline $\begin{array}{l}\text { Foreign products should be taxed heavily to reduce } \\
\text { their entry into Serbia. }\end{array}$ & 577 & 3,63 & 1.660 \\
\hline $\begin{array}{l}\text { We should buy from foreign countries only those } \\
\text { products that we cannot obtain within our own country. }\end{array}$ & 577 & 4,69 & 1.720 \\
\hline $\begin{array}{l}\text { Serbian consumers who purchase products made in } \\
\text { other countries are responsible for putting their fellow } \\
\text { Serbians out of work. }\end{array}$ & 577 & 2,87 & 1.647 \\
\hline & & & 1.665 \\
\hline
\end{tabular}

Looking at individual attitudes from the CETSCALE (Table 6) the attitudes with the highest acceptance are those that express the limitation of imports and reliance on domestic offer of the products that are produced in Serbia. The statement Buy 
Serbian-made products; Keep Serbia working with a mean score of 5.57 tops the list. The second-ranked statement is Only those products that are unavailable in Serbia should be imported. These two statements had also the highest values in earlier studies (Miladinović, 2012; Veljković, 2009). At the same time these are the only statements in the observed sample with the mean score above 5. The least accepted attitudes of the respondents were Purchasing foreign-made products is un-Serbian (mean score 2.34) and Foreigners should not be allowed to put their products on our markets (mean score 2.66). This is consistent with the aforementioned earlier studies, with a slight increase of the mean score.

Factor analysis has identified three dominant factors in consumer ethnocentrism that cover $64.026 \%$ of the variance, which confirms the hypothesis 3 . The first factor explains $48.408 \%$ of the variance, the second $9.222 \%$ of the variance, and the third $6.400 \%$ of the variance.

Table 6. Rotated Component Matrix ${ }^{a}$

\begin{tabular}{|l|c|c|c|}
\hline Statement & \multicolumn{3}{|c|}{ Component } \\
\cline { 2 - 4 } & 1 & 2 & \multicolumn{1}{|c|}{3} \\
\hline Purchasing foreign-made products is un-Serbian. & .761 & .241 & .172 \\
\hline $\begin{array}{l}\text { It is not right to purchase foreign products, because it puts the } \\
\text { Serbian people out of jobs. }\end{array}$ & .671 & .356 & .277 \\
\hline A real Serbian should always buy Serbian-made products. & .739 & .421 & .137 \\
\hline It is always best to purchase Serbian products. & .613 & .437 & .177 \\
\hline $\begin{array}{l}\text { Serbian people should not buy foreign products, because this } \\
\text { hurts Serbian business and causes unemployment. }\end{array}$ & .593 & .204 & .522 \\
\hline $\begin{array}{l}\text { Serbian consumers who purchase products made in other } \\
\text { countries are responsible for putting their fellow Serbians out of } \\
\text { work. }\end{array}$ & .663 & .070 & .382 \\
\hline $\begin{array}{l}\text { Foreigners should not be allowed to put their products on our } \\
\text { markets. }\end{array}$ & .629 & .045 & .512 \\
\hline $\begin{array}{l}\text { Serbian people should always buy Serbian-made products instead } \\
\text { of imports. }\end{array}$ & .259 & .754 & .055 \\
\hline $\begin{array}{l}\text { Only those products that are unavailable in Serbia should be } \\
\text { imported. }\end{array}$ & -.027 & .666 & .380 \\
\hline
\end{tabular}




\begin{tabular}{|l|c|c|c|}
\hline \multicolumn{2}{|l|}{ Statement } & \multicolumn{2}{|l|}{ Component } \\
\cline { 2 - 4 } & 1 & 2 & \multicolumn{1}{|c|}{3} \\
\hline Serbian products, first, last, and foremost. & .392 & .702 & .170 \\
\hline $\begin{array}{l}\text { We should purchase products manufactured in Serbia instead of } \\
\text { letting other countries get rich off us. }\end{array}$ & .460 & .562 & .307 \\
\hline $\begin{array}{l}\text { It may cost me in the long-run but I prefer to support Serbian } \\
\text { products. }\end{array}$ & .364 & .527 & .318 \\
\hline $\begin{array}{l}\text { There should be very little trading or purchasing of goods from } \\
\text { other countries unless out of necessity. }\end{array}$ & .483 & .128 & .621 \\
\hline Curbs should be put on all imports. & .086 & .304 & .734 \\
\hline $\begin{array}{l}\text { Foreign products should be taxed heavily to reduce their entry } \\
\text { into Serbia. }\end{array}$ & .386 & .086 & .673 \\
\hline $\begin{array}{l}\text { We should buy from foreign countries only those products that } \\
\text { we cannot obtain within our own country. }\end{array}$ & .051 & .514 & .657 \\
\hline
\end{tabular}

Extraction Method: Principal Component Analysis.

Rotation Method: Equamax with Kaiser Normalization.

a. Rotation converged in 22 iterations.

The first and most important factor that covers almost half of the variance in this article, is called ethical ethnocentrism. The claim Purchasing foreign-made products is un-Sebian $(0,761)$ has the greatest factorial saturation, followed by the statement $A$ real Serb should always buy Serbian-made products (0.739). Keywords of statements that show the greatest factorialsaturation are: not Serbian, should, it's not right, you should not. The claims from this factor mainly take the form of moral appeals and calls to buy domestic goods because it is generallygood for Serbia.

The second factor is called economic patriotism. The claims with the greatest factorial saturation are Buy Serbian-made products; Keep Serbia working (0.794) and Serbian people should always buy Serbian-made products instead of imports (0.754). Key words in the claims covered by this factor are Serbian and Serbian product. The focus is on stimulating domestic growth by purchasing domestic at the expense of imported goods.

The third factor is called radical consumer ethnocentrism. Radical ethnocentrism supports the implementation of protectionist measures in foreign trade of Serbia. The claims with the greatest factorial saturation are Curbs should be put on all imports (0.734) and Foreign products should be taxed heavily to reduce their entry into Serbia 
(0.673). Key words in the claims that cover this factor are related to the restriction of imports, imposing higher tax rates on imported goods, and import only what is necessary. The factor analysis isolated the factors whose order expresses gradation of the general acceptance of consumer ethnocentrism because it is good and morally justified for the Serbian economy, through direct calls to buy domestic in order to foster the development, to the open advocacy to introduce protectionist measures to protect domestic production from foreign competition.

Compared with previous research (Miladinović, 2012) only radical ethnocentrism occurs now in the same amount, indicating the presence of a solid extreme nationalistic core in public opinion. They are those who persist in supporting extreme nationalistic political parties in elections, and those who support any kind of social, economic and political isolation of Serbia from international community. The rest of the population is variable and takes the position on the wide scale of ethnocentrism, from mild - ethically motivated, over moderate to sharp ethnocentrism, depending on the current situation.

Due to the aforementioned political and economic developments, year 2014 saw increased ethnic homogenization in Serbia that was then transferred into the field of interethnic relations, as well as into the perception of the priorities in foreign trade exchange (Josifidis, et al., 2013). Part of the population not covered by the obtained factors generally corresponds to the number of those abstaining from parliamentary elections. Others can be divided into supporters and voters of parties that are part of broader 'political families' that could globally be classified into nationalist, nationaldemocratic and civic option (Komšić, et al., 2003; Todosijević 2016). In the long run, these three options are more or less a stable share of total voters in electorate, in that the parties are not ideologically homogeneous in the longer-term but are prone to occasional ideological reposition and transitions from one to another ideological camp. In this party-political galimatias, only the extreme national line can be said to have a firm core of electorate. The isolation of radical consumer ethnocentrism as a separate factor can be justified by the current distribution of political power in the Republic of Serbia and the growing discontent of the population due to a bad economic situation.

A relative growth of consumer ethnocentrism can be explained by the increasing awareness among the youth about high foreign trade deficit and Serbia's import dependence. Balance of current transactions recorded a negative value for the reference period of 2000-2012 with a tendency to increase negative values (in 2009 it amounted to $-6.6 \%$ of GDP, while in 2012 it amounted to $-10.7 \%$ of GDP). In 2013 the GDP recorded a growth rate of $2.6 \%$. Unfavourable foreign trade exchange is a reflection of poor competitiveness of the national economy (Ministry of Regional Development and Local Government of the Republic of Serbia, 2013, 2014). 


\section{Conclusions and limitations}

One of a series of sociological and psychological factors that influence consumer preference in the selection of goods they will buy when they come to the market is consumer ethnocentrism. Therefore it is understandable that there is a social interest to learn the limits of consumer ethnocentrism in Serbia because, on the basis of these findings, it is possible to prepare a long-term strategy for market penetration, not only of individual companies, but also of the entire national economy. This is also important for those who want to sell their goods on the Serbian market. Preferences of young Serbian towards buying local products are the result of socio-economic environment, as well as a current political climate in Serbia. Thus, the trend of increasing consumer ethnocentrism does not surprise. However, this slight increase is still within the limits of moderate consumer ethnocentrism measured by the CETSCALE. These results are complementary to previous studies conducted in the Republic of Serbia (Marinković, Stanišić, and Kostić 2011; Miladinović 2012; Veljković 2009; Vida, Dmitrovic and Obadia 2008). Factors of consumer ethnocentrism in Serbia indicate that young people are primarily motivated by ethical and economic reasons for the purchase of domestic products. Consequently, young people have developed awareness that this is a way one should help the local economy to recover. A smaller number of respondents felt that it should act radically to protect national economy.

Considering the sample, limitations of the research are inability to deeper analyze consumer ethnocentrism by age, educational attainment and employment. It also ignores income as a crucial factor in making consumer decisions (Josiassen, Assaf, and Karpen 2011). As the sample comprised only student population, it is clear that it refers to part of the population that mostly does not have its own sources of income and a steady job. In addition, the sample included only the student population of the University of Belgrade, Faculty of Organizational Sciences. The question is whether the findings could be different if the data were collected across other universities in Serbia. A direction of future research could be determined in this sense. 


\section{REFERENCES}

Acharya, C. and Elliott, G. (2003). Consumer ethnocentrism, perceived product quality and choice: an empirical investigation. Journal of International Consumer Marketing 15 (4): 87-115.

Balabanis, G. and Diamantopoulos, A. (2004). Domestic country bias, country-of-origin effects, and consumer ethnocentrism: a multidimensional unfolding approach. Journal of the Academy of Marketing Science 32 (1): 80-95.

Bar-Tal, D. (1990). Causes and consequences of delegitimization: Models of conflict and ethnocentrism. Journal of Social Issues 46 (1): 65-81.

Berna, IB. (2013). The Role of European Economic Diplomacy in the Western Balkans. Economics, Management, and Financial Markets 4 (1): 196-201.

Bjelić, P. (2011). Marketing instruments of foreign trade promotion. Marketing 42 (4): 268-276.

Block, J. and Block, J. (1951). An investigation of the relationship between intolerance of ambiguity and ethnocentrism. Journal of Personality 19 (3): 303-311.

Budimir, B., Radić, I. and Kahrimanović, V. (2008). Guide to the Stabilization and Association Agreement. Belgrade: ISAC Fund.

Caruana, A. (1996). The effects of dogmatism and social class variables on consumer ethnocentrism in Malta. Marketing Intelligence \& Planning 14 (4): 39-44.

Chryssochoidis, G., Krystallis, A. and Perreas, P. (2007). Ethnocentric beliefs and country-oforigin (COO) effect: impact of country, product and product attributes on Greek consumers' evaluation of food products. European Journal of Marketing 41 (11/12): 1518-1544.

Cordell, V.V. (1992). Effects of consumer preferences for foreign sourced products. Journal of International Business Studies 23 (2): 251-269.

Crawford, J. C. and Lamb, C.W. (1981). Source preferences for imported products. Journal of Purchasing and Materials Management 17 (4): 28-33.

Druckman, D. (1968). Ethnocentrism in the inter-nation simulation. Journal of Conflict Resolution 12 (1): 45-68.

Durvasula, S., J., Andrews, J.C. and Netemeyer, R.G. (1997). A cross-cultural comparison of consumer ethnocentrism in the United States and Russia. Journal of International Consumer Marketing 9 (4): 73-93.

Estrin, S. and Uvalic, M. (2014). FDI into transition economies. Economics of Transition 22 (2): 281-312.

European Bank for Reconstruction and Development (2013). Transition report 2013: Stuck in Transition. London: European Bank for Reconstruction and Development.

European Integration Office (2011). European orientation of the citizens of the Republic of Serbia. Belgrade: Government of the Republic of Serbia.

European Integration Office (2012). European orientation of the citizens of the Republic of Serbia. Belgrade: Government of the Republic of Serbia.

European Integration Office (2013). European orientation of the citizens of the Republic of Serbia. Belgrade: Government of the Republic of Serbia. 
Forbes, H.D. (1985). Nationalism, ethnocentrism, and personality. Chicago: University of Chicago Press.

Good, L.K. and Huddleston, P. (1995). Ethnocentrism of Polish and Russian consumers: are feelings and intentions related. International Marketing Review 12 (5): 35-48.

Hamin, H. and Elliott, G. (2006). A less-developed country perspective of consumer ethnocentrism and "country of origin" effects: Indonesian evidence. Asia Pacific Journal of Marketing and Logistics 18 (2): 79-92.

Harrison, R. (2003). Corporate social responsibility and the consumer movement. Consumer Policy Review 13 (4): 127-131.

Hrvatin, S.B. and Trampuž, M. (2000). Enjoy your enemy or how the Kosovo (media) war broke out. Javnost-The Public 7 (3): 77-85.

Hult, G.T.M., Keillor, B.D. and Lafferty, B.A. (1999). A cross-national assessment of social desirability bias and consumer ethnocentrism. Journal of Global Marketing 12 (4): 29-43.

Josiassen, A., Assaf, A.G. and Karpen, I.O. (2011). Consumer ethnocentrism and willingness to buy: Analyzing the role of three demographic consumer characteristics. International Marketing Review 28 (6): 627 - 646.

Josifidis, K., Allegret, JP. and Pucar E.B. (2013). Adjustment mechanisms and exchange rate regimes in 2004 new EU members during the financial crisis. Post-Communist Economies 25 (1): 1-17.

Klein, J. G. (2002). Us versus them, or us versus everyone? Delineating consumer aversion to foreign goods. Journal of International Business Studies 33 (2): 345-363.

Klein, J.G. and Ettensoe R. (1999). Consumer animosity and consumer ethnocentrism: an analysis of unique antecedents. Journal of International Consumer Marketing 11 (4): 5-24.

Komšić, J., Pantić, D. and Slavujević, Z.Đ. (2003). Basic lines of party division and possible directions of political realignment in Serbia. Belgrade: Friedrich Ebert Stiftung and Institute of Social Sciences.

Korovilas, J. P. (2002). The economic sustainability of post-conflict Kosovo. Post-communist economies 14 (1): 109-121.

Kosterman, R. and Feshbach, S. (1989). Toward a Measure of Patriotic and Nationalistic Attitudes. Political Psychology 10 (2): 63-92.

Kragulj, D. (2013). Economics - Basis of microeconomic and macroeconomic analysis. Belgrade: published by the author.

Levine, R.A., and Campbell, D.T. (1972). Ethnocentrism: Theories of conflict, ethnic attitudes, and group behavior. Oxford: John Wiley \& Sons.

Marinković, V., Stanišić N. and Kostić, M. (2011). Consumer ethnocentrism of Serbian citizens. Sociologija 56 (1): 43-58.

Miladinović, S. (2012). Consumer ethnocentrism research: first findings. In Levi-Jakšić, M. and Barjaktarović-Rakočević, S. (ed.), Innovative management and business performance, Belgrade: Faculty of organizational sciences, pp. 329-333.

Ministry of Regional Development and Local Government of the Republic of Serbia (2013). Development Report Serbia 2012. Belgrade: Ministry of Regional Development and Local Government of the Republic of Serbia. 
Ministry of Regional Development and Local Government of the Republic of Serbia (2014). The Actual Development Trends. Belgrade: Ministry of Regional Development and Local Government of the Republic of Serbia.

National Bank of Serbia (2015). Key macroeconomic indicators. Belgrade: National Bank of Serbia. $<$ http://www.nbs.rs/internet/english/80/index.html $>1.12 .2015$.

O'Cass, A. and Lim, K. (2002). Toward understanding the young consumer's brand associations and ethnocentrism in the lion's port. Psychology \& Marketing 19 (9): 759-775.

Ram, S. and Sheth, J.N. (1989). Consumer resistance to innovations: the marketing problem and its solutions. Journal of Consumer Marketing 6 (2): 5-14.

Rokeach, M. (1948). Generalized mental rigidity as a factor in ethnocentrism. The Journal of Abnormal and Social Psychology 43 (3): 259-278.

Schnettler, B., Miranda, H., Lobos, G., Sepúlveda, J. and Denegri M. (2011). A study of the relationship between degree of ethnocentrism and typologies of food purchase in supermarkets in central-southern Chile. Appetite 56 (3): 704-712.

Šestović, L. and Miović, P. (2013). Serbia Country Economic Memorandum: Productivity and Exports. Washington: World bank.

Shah, K.A.M. and Ibrahim, H.I. (2012). Consumer ethnocentrism: Does It Really Matter For Malaysian Consumers. West East Journal of Social Sciences 1 (1): 26-38.

Sharma, S., Shimp, T.A. and Shin, J. (1995). Consumer ethnocentrism: a test of antecedents and moderators. Journal of the Academy of Marketing Science 23 (1): 26-37.

Shimp, T.A. (1984). Consumer ethnocentrism: the concept and a preliminary empirical test. Advances in Consumer Research 11 (1): 285-290.

Shimp, T.A. and Sharma, S. (1987). Consumer ethnocentrism: construction and validation of the CETSCALE. Journal of Marketing Research 24 (3): 280-289.

Sirgy, M. J. (1982). Self-concept in consumer behavior: a critical review. Journal of Consumer Research 9 (3): 287-300.

Statistical Office of the Republic of Serbia (2011). Projections of the labor force of the Republic of Serbia 2010-2050. Belgrade: Statistical Office of the Republic of Serbia.

Statistical Office of the Republic of Serbia (2015). Statistical Database. Belgrade: Statistical Office of the Republic of Serbia. $<$ http://webrzs.stat.gov.rs/WebSite/> 1.12.2015.

Steenkamp, JB. EM. and Baumgartner, H. (1998). Assessing measurement invariance in crossnational consumer research. Journal of Consumer Research 25 (1): 78-107.

Strehlau, V.I., Ponchio, M.C.and Loebel, E. (2012). An Assessment of the consumer ethnocentric scale (CETSCALE): evidences from Brazil. Brazilian Business Review 9 (4): 103-126.

Sumner, W.G. (1906). Folkways: A Study of the Sociological Importance of Usages, Manners, Customs, Mores and Morals. Boston: Grinn \& Co.

Teo, P., Mohamad, O. and Ramayah T.(2011). Testing the dimensionality of Consumer Ethnocentrism Scale (CETSCALE) among a young Malaysian consumer market segment. African Journal of Business Management 5 (7): 2805-2816.

Todosijević, B. (2016). Left-right ideology: its meaning and effects on party preferences in Serbia. Социолошки преглед 50 (2): 161-178. 
D. Kragulj, M. Parežanin, S. Miladinović, Consumer Ethnocentrisam...

Upadhyay, Y. and Singh, S.K. (2006). Preference for domestic goods: A study of consumer ethnocentrism. Vision: The Journal of Business Perspective 10 (3): 59-68.

Veljković, S. (2009). The influence of ethnocentrism on consumers in Serbia. Marketing 10 (2): 97-106.

Vida, I. and Fairhurst, A. (1999). Factors underlying the phenomenon of consumer ethnocentricity: evidence from four central European countries. The International Review of Retail, Distribution and Consumer Research 9 (4): 321-337.

Vida, I. and Reardon, J. (2008). Domestic consumption: rational, affective or normative choice? Journal of Consumer Marketing 25 (1): 34-44.

Vida, I., Dmitrovic, T. and Obadia, K. (2008). The role of ethnic affiliation in consumer ethnocentrism. European Journal of Marketing 42 (3/4): 327-343.

Watson, J. J. and Wright, K. (2000). Consumer ethnocentrism and attitudes toward domestic and foreign products. European Journal of Marketing 34 (9/10): 1149-1166.

Witkowski, T.H. (1998). Consumer Ethnocentrism in Two Emerging Markets: Determinants and Predictive Validity. In Alba J.W. and Hutchinson J.W. (ed.) Advances in Consumer Research, Provo: Association for Consumer Research, pp. 258-263.

Yoo, B. and Donthu, N. (2005). The effect of personal cultural orientation on consumer ethnocentrism: evaluations and behaviors of US consumers toward Japanese products. Journal of International Consumer Marketing 18 (1/2): 7-44. 


\author{
Драгана Крагуљ \\ Милош Парежанин \\ Слободан Миладиновић \\ Универзитет у Београду \\ Факултет организационих наука
}

\title{
ПОТРОШАЧКИ ЕТНОЦЕНТРИЗАМ У ЗЕМЉАМА У ТРАНЗИЦИЈИ: ПРИМЕР СРБИЈЕ
}

Сажетак: У раду се истражује потрошачки етноцентризам младих међу студентском популацијом у Републици Србији. Циљ истраживања је да се испита да ли је дошло до раста у нивоу потрошачог етноцентризма код младих у Србији с обзиром на све негативне демографске и економске околности, као и политичке турбулениије у земљи. Истраживање је спроведено анкетирањем студената на Универзитету у Београду, применом CETSCALE и факторском анализом. Добијене вредности CETSCALE указују на то да је потрошачки етночентризам у гранищама умереног, али се исто тако бележи благи узлазни тренд у односу на претходна истраживања. Изоловане су три скупине фактора: етички етночентризам, економски патриотизам и радикални потрочачки етноцентризам. Фактори указују на то да различити међусобно испреплетани мотиви утичу на избор младих људи да купују домаће производе. Преференције младих према куповини домаћих производа су резултат како социо-економског окружења тако и тренутне политичке климе у Србији.

Кључне речи: потрочач, етноцентризам, CETSCALE, студент, Србија. 